\title{
Retraction Note to: Urban land ecological evaluation and English translation model optimization based on machine learning
}

\section{Lin Wang ${ }^{1}$}

Published online: 12 November 2021

(c) Saudi Society for Geosciences 2021

Retraction Note to: Arabian Journal of Geosciences (2021) 14: 1023 https://doi.org/10.1007/s12517-021-07334-6

The Editor-in-Chief and the Publisher have retracted this article because the content of this article is nonsensical. The peer review process was not carried out in accordance with the Publisher's peer review policy. The author has not responded to correspondence regarding this retraction.

The original article can be found online at https://doi.org/10.1007/ s12517-021-07334-6.

Lin Wang

linda2078@126.com

1 College of Foreign Languages, University of Shanghai for Science and Technology, Shanghai 200093, China 